\title{
Lymphomatous orbital infiltration and vision loss in diffuse large B-cell lymphoma
}

\author{
Seongseok Yun, ${ }^{1}$ Jocelyn Ko, ${ }^{1}$ Nicole D Vincelette, ${ }^{2}$ Faiz Anwer ${ }^{1}$
}

${ }^{1}$ Department of Internal Medicine, University of Arizona Medical Center, Tucson, Arizona, USA

${ }^{2}$ Department of College of Medicine, Mayo Clinic, Rochester, Minnesota, USA

\section{Correspondence to} Dr Seongseok Yun, namaska97@gmail.com

Accepted 3 May 2014
CrossMark

To cite: Yun $\mathrm{S}$, Ko J, Vincelette ND, et al. BMJ Case Rep Published online: [please include Day Month Year] doi:10.1136/bcr-2014204613

\section{DESCRIPTION}

A previously healthy 54 -year-old man presented with gradual vision loss, pain and swelling of the left eye, which started a month prior to admission. He was also experiencing night sweat, mild fever and noticed $10 \mathrm{lb}$ weight loss since symptoms started. Physical examination showed inferior chemosis, lagophthalmos and mild proptosis of the left eye. Head CT showed a left-sided paranasal mass (figure 1), and subsequent MRI demonstrated a large lobulated infiltrative mass centred in the upper left nasal cavity with extension into the left orbits with resultant moderate proptosis and stretching of the optic nerve (figure 2A, B). CT of the chest, abdomen and pelvis revealed no evidence of lymphadenopathy or hepatosplenomegaly. Also, a bone marrow biopsy showed no lymphoid aggregate or interstitial increase of lymphocytes with normal flow cytometry results. A biopsy from the mass confirmed the diagnosis of stage IE extranodal diffuse large B-cell lymphoma (DLBCL) with strong expression of MUM1, CD5, BCL2, CMYC and BCL6, but negative CD3 and $\mathrm{CD} 10$ (figures $3 \mathrm{~A}, \mathrm{~B}$ and $4 \mathrm{~A}-\mathrm{G}$ ), suggesting an aggressive course of disease. ${ }^{1-3}$ Intravenous prednisone was initiated to minimise optic nerve compression and chemotherapy with rituximab, cyclophosphamide, doxorubicin, vincristine and prednisone (R-CHOP) was started alternating with intravenous methotrexate for central nervous system prophylaxis. ${ }^{45}$ The patient completed three courses of R-CHOP, with only partial recovery of visual acuity from $20 / 200$ to $20 / 100$ in a Snellen chart. Paranasal DLBCL is a very rare disease and results in

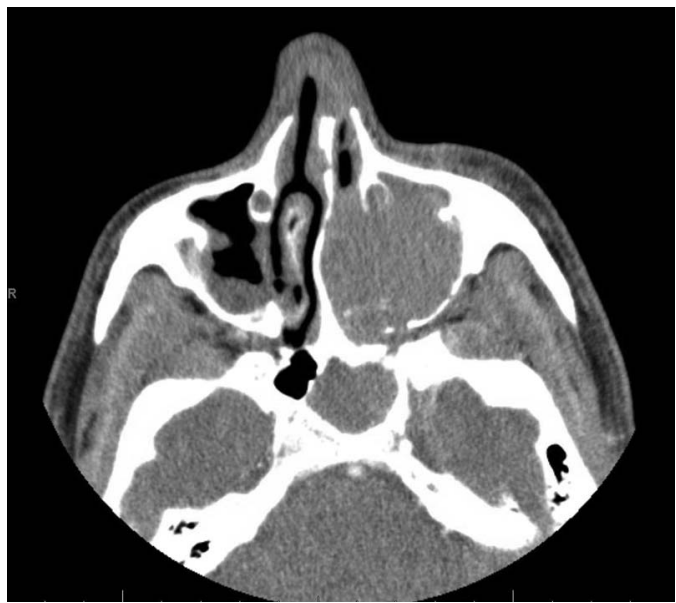

Figure $1 \mathrm{CT}$ of the head. A large infiltrative mass measuring about $47 \times 47 \times 38 \mathrm{~mm}$ with mild heterogeneous enhancement is seen centred around the left nasal cavity. This mass is causing destruction of the medial, inferior wall of the left orbit. optic nerve compression causing blindness. Prolonged optic nerve compression can lead to irreversible vision loss. Early diagnosis with imaging modalities is pivotal for the prognosis and steroid treatment is essential to minimise the complications from optic nerve compression.
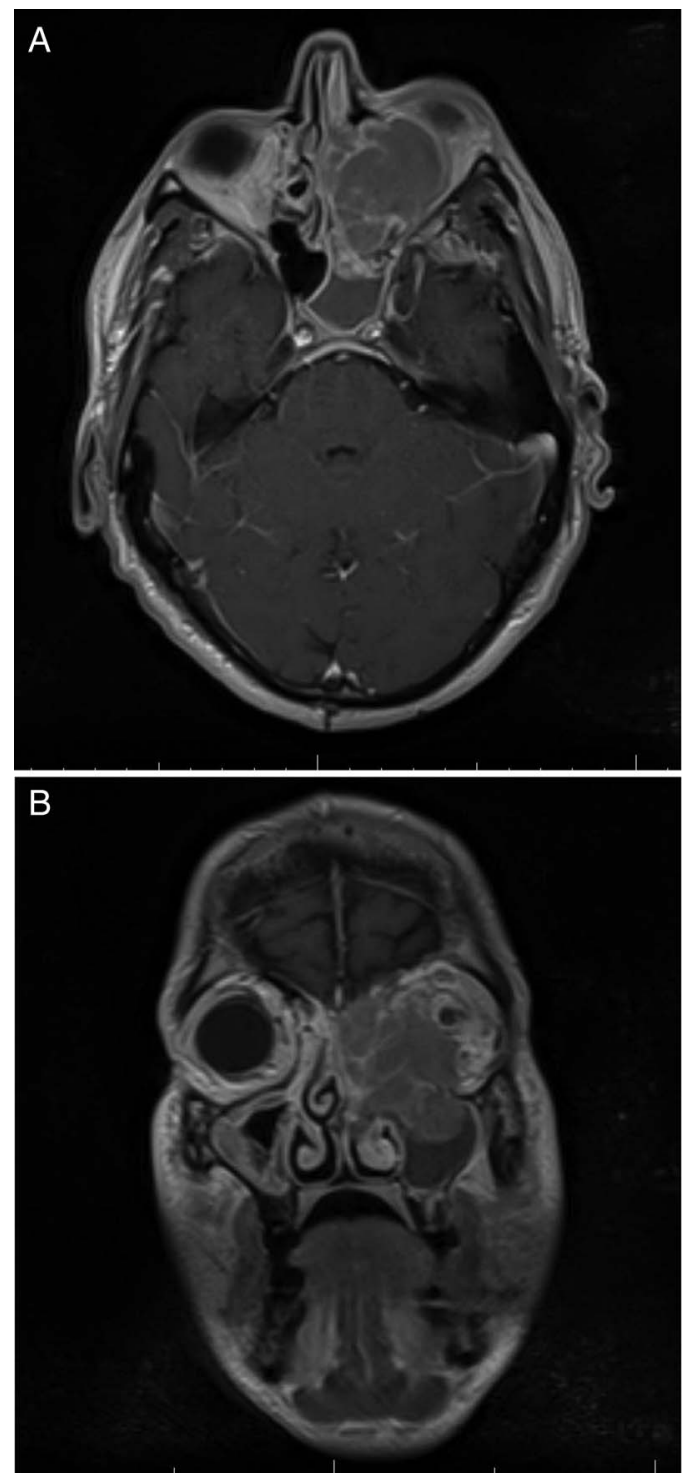

Figure 2 (A and B) MRI of the brain. A T1 postcontrast large lobulated infiltrative mass centred in the upper left nasal cavity, with extension into the left orbit with resultant moderate proptosis and stretching of optic nerve, is causing destruction of the left middle turbinate, uncinate process. The mass is extending into the maxillary sinus and also causing erosion and destruction of the cribriform plate, fovea ethmoidalis, wall of frontal sinus and anterior wall of sphenoid sinus on the left side with probable extension into the epidural space and sphenoid sinus. 
Figure 3 (A and B) Light microscopic findings evaluation of the biopsy specimens from the paranasal mass at $\times 100(A)$ and $\times 400(B)$ showing neoplastic B-cell proliferation characterised by overall large cell size and centroblastic morphology.
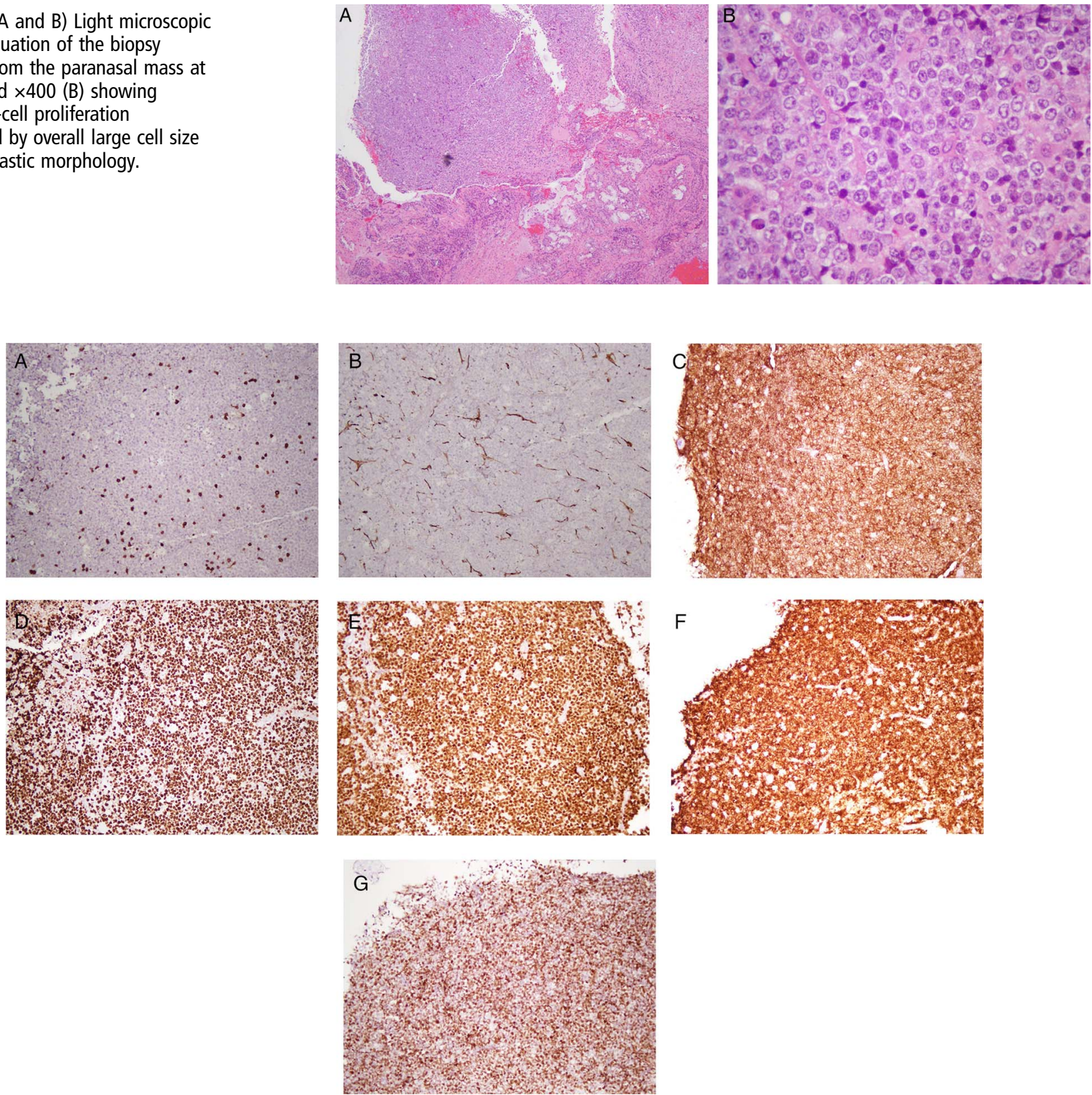

Figure 4 (A-G) Immunohistochemistry staining. The absence of CD3 (A), CD10 (B) with expression of CD5 (C), BCL6 (D), MUM-1 (E) classify this diffuse large B-cell lymphoma as of non-germinal centre origin and activated cell type. ${ }^{3}$ In addition, these cells express strong BCL2 (F), CMYC (G) and BCL6 (D). These findings suggest triple hit lymphoma with poor prognosis. ${ }^{12}$

\section{Learning points}

- Extranodal diffuse large B-cell lymphoma can present with paranasal mass and orbital infiltration in rare cases.

- Prolonged optic nerve compression by mass can cause irreversible vision loss, and immediate steroid and chemotherapy are essential for a better clinical outcome.
Contributors SY, JK and FA were involved in care of the patient, collecting data and all of the authors wrote up the case report. SY reviewed the literature and revised the manuscript.

Competing interests None.

Patient consent Obtained.
Provenance and peer review Not commissioned; externally peer reviewed.

\section{REFERENCES}

1 Thieblemont $C$, Brière J. MYC, BCL2, BCL6 in DLBCL: impact for clinics in the future? Blood 2013;121:2165-6.

2 Horn $\mathrm{H}$, Ziepert M, Becher $\mathrm{C}$, et al. MYC status in concert with BCL2 and BCL6 expression predicts outcome in diffuse large B-cell lymphoma. Blood 2013;121:2253-63.

3 Hans CP, Weisenburger DD, Greiner TC, et al. Confirmation of the molecular classification of diffuse large B-cell lymphoma by immunohistochemistry using a tissue microarray. Blood 2004;103:275-82.

4 Feugier $\mathrm{P}$, Van Hoof $A$, Sebban $C$, et al. Long-term results of the R-CHOP study in the treatment of elderly patients with diffuse large B-cell lymphoma: a study by the Groupe d'Etude des Lymphomes de l'Adulte. J Clin Oncol 2005;23: 4117-26.

5 Abramson JS, Hochberg M, Barnes JA, et al. Intravenous methotrexate as central nervous system (CNS) prophylaxis is associated with a low risk of CNS recurrence in high-risk patients with diffuse large B-cell lymphoma. Cancer 2010;116:4283-90. 
Copyright 2014 BMJ Publishing Group. All rights reserved. For permission to reuse any of this content visit http://group.bmj.com/group/rights-licensing/permissions.

BMJ Case Report Fellows may re-use this article for personal use and teaching without any further permission.

Become a Fellow of BMJ Case Reports today and you can:

- Submit as many cases as you like

- Enjoy fast sympathetic peer review and rapid publication of accepted articles

- Access all the published articles

- Re-use any of the published material for personal use and teaching without further permission

For information on Institutional Fellowships contact consortiasales@bmjgroup.com

Visit casereports.bmj.com for more articles like this and to become a Fellow 